\title{
Knowledge Workers: How Are They Different? (And Why Does It Matter?)
}

\author{
Abdallah Wumpini Issahaka \\ Norwegian School of Economics \\ Rune Lines \\ Norwegian School of Economics
}

In this study, we integrate research in educational psychology, a field that partly has focused on the global effects of higher education on individuals to conceptualize and test a model that explains how knowledge workers can be thought to differ from other groups of workers. Conceptualizing a common constellation of personality dispositions associated with knowledge workers (i.e., ambiguity tolerance, need for closure, dogmatism, authoritarianism, and cognitive ability), we propose multiple outcome pathways by which individual-level education affects the five personality traits under study. Based on a nest 5 ed sample of 351 employees across 54 workgroups, the results were consistent with our predictions.

Keywords: Knowledge Workers, Education Effects, Psychosocial Changes

\section{INTRODUCTION}

With the shift into a knowledge economy, management scholars and practitioners alike (Alvesson, 2001; Darr \& Warhurst, 2008; Drucker, 1959, 1999; Kelloway \& Barling, 2000), emphasize the growing importance of knowledge and knowledge work processes in value-creation. A growing body of research demonstrates the crucial role of highly skilled professionals to engage in knowledge work processes, and therefore suggests that knowledge workers, individuals in whose heads knowledge resides, are assets to be valued, stimulated and managed in an organization (e.g., Tompoe, 1993; Stewart and Ruckdeschel, 1998; Drucker, 2002; Bogdanowicz and Bailey, 2002; Lewis, Agaewal and Sambamurthy, 2003; Davenport, 2005).

The knowledge economy describes a new wave of development in global economic restructuring away from the industrial revolution age (Blair, 1998; OECD, 2001; Reich, 1993). Knowledge has substituted manual work as a base for industrial production. This evolution has created an increasing workforce of highly skilled professionals, called knowledge workers (Machlup, 1962; Noyelle, 1990; Stanback, 1979); a vibrant innovation landscape (Bell, 1973; Drucker, 1993; Nonaka \& Takeuchi, 1995; Prusak, 2009; Von Nordenflycht, 2010); and the emergence of knowledge-based organizations (Bell, 1973, 1979; Davenport, Thomas, \& Cantrell, 2002; Drucker, 1959; Mandt, 1978). Indeed, the basis for competitive advantage now depends more on employee creativity and intellectual capabilities to produce and distribute novel ideas. Hence, the need for greater reliance on intellectual capabilities for sustainable economic growth and to achieve the primary management task of value creation cannot be 
overemphasized (Bettis \& Hitt, 1995; Conner \& Prahalad, 1996; Hitt, Keats, \& DeMarie, 1998; Powell \& Snellman, 2004).

The research attention on knowledge workers is growing alongside the rhetoric of 'knowledge management,' 'leadership,' and 'human resource management' explicitly devoted to understanding knowledge workers and finding pathways to manage them effectively. Based on a literature review, we distinguish between two broadly observed approaches that define and conceptualize knowledge workers. The first is from authors (Drucker, 1994; Hislop, 2008; Benson and Brown, 2007; Darr and Warhurst, 2008) that identify with a 'job-content' approach, in which focus is on what knowledge workers do and the activities in which they are engaged. The second, as exemplified by Davenport and colleagues (Davenport et al., 2002), espouse a viewpoint that focuses on prerequisite qualities, skills, and capabilities necessary for an individual to handle knowledge work in a primary role. A commonly associated attribute is that of their high education and expertise skills. For example, consultants (Donnelly, 2009), medical professionals (Mastekaasa, 2011), and accountants (Von Nordenflycht, 2010) are considered to be professional persons (i.e., knowledge workers) with a high degree of formal education and knowledge expertise.

Under the job-content approach, at least three lines of studies are identified. The first line of research, dating back to the 1960s, focused on the rise of knowledge-intensive industries/firms. 'Occupation-driven analysis' dominates this stream of research towards an understanding of knowledge workers (Darr \& Warhurst, 2008, p. 26). A shared ideology among scholars using this concept is the level of sophistication and intensive use of knowledge associated with the job (Alvesson, 2001; Hunter, Beaumont, \& Lee, 2002; Robertson \& Swan, 2003). Professions conceptualized under this category include scientists and engineers (Beaumont \& Hunter, 2002; Quinn, 2005), lawyers (Hunter et al., 2002), accountants (Morris \& Empson, 1998), and information technology and software workers (Choi \& Varney, 1995; Swart \& Kinnie, 2003). The second line of studies focused on the emergence of new kinds of jobs and novel forms of work organization. These studies argue that knowledge work is not restricted to a handful of industries but is more widespread, involving a series of changes to the nature of work (activities). Knowledge work is designed to encourage job autonomy, decentralization, teams, and networks. The third line of studies focused on the role of learning and continuous innovation within firms. This approach describes knowledge work in terms of individuals' outcomes as opposed to job characteristics. It emphasizes value creation mediated by creativity and innovation as a core element to identifying knowledge work (e.g., Wikström \& Norman, 1994). A focus on the nature of individual workplace outcomes deviates from the occupation-driven analysis towards a consideration of what an individual contributes (Kelloway and Barling, 2000: 290). That is, the output of individuals within knowledge work must represent creativity, innovation, and value creation (Maruta, 2012).

However, conceptual unclarity plagues the job-content approach and seemingly accounts for the lack of consensus on how knowledge workers should be defined and understood. Research discussions on the definition and 'images' of knowledge workers have largely remained conceptual and draw upon a loose consortium of propositions derived from the literature on the 'knowledge economy,' 'know-work processes' and 'knowledge-based organizations.' As such, many studies end up listing professions or industries taken as examples of knowledge workers, knowledge work, and knowledge-based organizations. Systematic empirical research on the concept of knowledge workers is scarce. Hence, contributions to knowledge work/er research demonstrate little in the way of common theoretical underpinnings to guide its development.

On the other hand, formal education as a defining factor of a knowledge worker has received the unequivocal agreement. Indeed, formal education and experience are seen to be a key input shaping the workforce needed in the knowledge economy. However, the implications of that difference (higher education) are not explicitly studied. It begs the question, how are persons with higher education different from persons similar in other aspects but without (higher) education? A further question is: what are the implications for leadership and management in the context of knowledge workers if we look at them as highly educated individuals? Although a few studies have proposed leadership styles and organizational structures for managing knowledge workers, none is formally grounded on how they are different from 
other groups of workers. To fill this literature gap, the need for a firmer theoretical background on knowledge workers that can be subjected to rigorous empirical testing is imperative.

As Doty and Glick (1994) exemplified, typologies are a unique form of theory building towards improved understanding and modeling. We utilize typologies to achieve a parsimonious framework that conceptualizes knowledge workers based on a common constellation of individual-difference dispositions associated with knowledge workers and distinguish them from other workers. In this way, our theorizing is enriched by adopting a focus based on individual-level dispositional tendencies associated with (higher) education. Defining knowledge workers as highly educated individuals, we draw on the body of research in educational psychology to propose and test a model that clarifies a dispositional view of educationeffects on individuals. That is, we identify personality traits and dispositional tendencies that distinguish groups of individuals that are similar in many aspects but differ on educational level.

The remainder of the paper is structured as follows. The next section describes the theoretical framework and hypotheses. Adopting typologies as theory-building tools, we review the developmental theories of student change to identify and discuss the elicitation of personality dispositions as a response to college effects (education) and also examine, the contextual role of aging and organizational structures on the relationship between education and personality dispositions in a workplace setting. The research method and results follow next. Lastly, the contributions and implications of this research and directions for future research are discussed.

\section{THEORY AND HYPOTHESES}

\section{Theories and Models of Student Development}

The importance of education in shaping attitudes, values, and norms has, for a long time, received acknowledgment among social scientists. Student development refers to "the ways that a student grows, progresses, or increases [their] developmental capabilities as a result of enrollment in an institution of higher education" (Rodgers, 1990: 27). Theories of student development and change has been conceptualized in at least three related clusters: as developmental theories of student change (e.g., Chickering, 1969; Perry, 1970, 1981) -addresses the nature, structure, and processes of individual human growth; as college impact models (e.g., Alexander W Astin, 1984; Alexander William Astin, 1985; Pascarella, 1985; Tinto, 1975, 1987) emphasizing change associated with characteristics of the institutions students attend (between-college effects) or with the experience students have while enrolled (within-college effects); and as socialization models (e.g., Kaufman \& Feldman, 2004) to understand the origins of change in students external rather than internal worlds.

In this study, we take the first family of theories focused primarily on the nature and content of intraindividual change and "view development as a general movement towards greater differentiation, integration, and complexity in the ways that individuals think and behave" (Pascarella and Terenzine, 2005: 19). Often, the movement is seen as orderly, sequential and hierarchical (usually across the life span), passing through ever higher and more complex stages that are to some extent age-related (Pascarella \& Terenzini, 1991, 2005). Several taxonomies of developmental theories exist, each with its advantages. In a comprehensive review of theories and models of student development, Pascarella and Terenzini $(1991 ; 2005)$ accommodate the growth of identity theories by adopting and revising the fourcategory structure initiated by Knefelkamp, Widick, and Parker (1978) and revised by Rodgers (1989). The four clusters of theories are psychosocial development theories, cognitive-structural theories, typological models, and Person-environment interaction theory and models.

\section{Psychosocial Theories}

Psychosocial theories emphasize the self-reflective and interpersonal dimensions of students' lives. It views individual development essentially as a sequential process that involves the accomplishment of a series of developmental tasks. This family of theories asserts that the nature of tasks and challenges is influenced in part, as a consequence of age progression and, partly as a consequence of sociocultural (environmental) influences. Influential theories within psychosocial theories include Chickering's (1969) theory of identity development (i.e., seven vectors of student development); Erikson (1959; 1963, 1968) 
identity models; Marcia's (1964; 1966) model of ego identity status; and Heath's maturity model (1978; 1968). These theories describe how students' perspectives of their own identity and society evolve through the conflicts and challenges they experience. Hence, the underlying core values are conflict, independence, interdependence, and autonomy.

\section{Cognitive-Structural Theories}

Cognitive-structural theories seek to describe the process of change. Change refers to alterations that occur over time in students' internal cognitive or affective characteristics (Pascarella and Terenzini, 1991: 16). This family of theories explains how students think, reason, organize, and make meaning of their experiences. Complimentary to the psychosocial theory, "One describes what students will be concerned about and what decisions will be primary; the other suggests how students will think about those issues and what shifts in reasoning will occur" (Knefelkamp, Widick, \& Parker, 1978 p. xii). A shared assertion by cognitive-structural theories is that individuals go through a sequential process, with cognitive development unfolding by stages as students build upon past experiences. Also, the cognitive development process is considered hierarchical, and the progression is irreversible.

Perry's $(1970,1981)$ theory of intellectual development identified describes the typical course of development of student's patterns of thoughts. It is a stage model of students moving through nine sequential positions in four general categories. The sequential stages are dualism, multiplicity, relativism, and commitment in relativism. Perry's model illustrates a "logical order in which one form leads to another through differentiation and reorganizations required for the meaningful interpretation of increasingly complex experience" (1970: 3). Thus, one is not capable of understanding anything that more than one step beyond where they are, and that cognitive development is promoted by encounter with difference and diversity.

Another cognitive "stage" theory is Kohlberg's theory of moral development (1969, 1972, 1981, 1984). Away from Perry's approach focused on cognitive and ethical growth, Kohlberg's theory of moral development explains how students' ability to reason affects their behavior and conduct. The theory describes six stages of moral development categorized into three levels of moral reasoning. Sequential progression from a pre-conventional level, to conventional level, and to post-conventional level requires students to go through moral conflicts and to develop a sense of personal responsibility for their actions and ultimately for a morally just society. Kohlberg's work has inspired new theories by subsequent researchers (cf. Gilligan, 1977; Loevinger, 1976). Theories in development of college students' ethics, faith, and spirituality have arisen from Kohlberg's work. Overall, teaching, learning, reflection, change, and empathy are the values that underlie many cognitive-structural theories.

\section{Typological Models}

Typological models emphasize distinct but relatively stable differences among individuals. These models categorize individuals into groups according to some distinctive characteristics, such as personality (see Myers, 1976; Myers, McCaulley, \& Most, 1985). There are several commonalities among "type" models. First, preferences or styles that characterize individuals and differentiate them are assumed to develop relatively early in life and to remain comparatively stable, although not invariant, over time. Second, an individual may demonstrate characteristics indicative of other types within the taxonomy but tend to think or behave in ways consistent with the distinctive features or preferences of the dominant type. Third, type categories describe areas of preference or tendencies that people have in common, but they do not explain idiosyncratic differences. That is, it emphasizes a focus on the intraindividual structure of personality, and encourages a consideration of the constellation of personality characteristics at an individual level. According to Rodgers, they constitute "various tracts of wholeness," 'zipcode' areas within which they grow and develop (1989: 153). Finally, these models generally do not attempt to explain either the content or processes of change or development in students (Pascarella and Terenzini, 2005:46).

Nonetheless, typological models are useful in understanding differences between individuals based on education and in illuminating why educated individuals may respond in ways different from other groups of individuals without college experience. Thus, type theories provide conceptual clarity to characterizing 
groups of individuals by shared traits. Efficiently collapsing across a broad range of descriptors into a concise typology gives insight into the underlying etiology driving the relationship among the traits, thus delivering a richer and more coherent theory of personality.

\section{Person-Environment Interaction Models}

Person-environment interaction models focus in detail on how the environment influences behavior through its interactions with individuals' characteristics. Differently stated, these theories describe how student's behavior and growth are directly affected by the educational environment. Like the typology models, they do not explain the nature of processes of student development but identify some origins of behavior and provide frameworks for discussing student change and college effects.

These theories identify substantive and process features associated with highly educated individuals, and by extension, knowledge workers. These theories guide our selection of potentially important and theoretically grounded variables. As such, we will draw attention to the prominent ones among them. The section that follows, therefore, explicate conceivable links between conceived stable individual-difference personality dispositions and collage effect (i.e., education), to form a personality-based concept of knowledge workers. Indeed, a small but growing number of studies have aimed to capture the human spark of education by reconceiving educational impact as dispositional in nature, rather than abilitiescentric (e.g., Ennis, 1991; D. Perkins, Tishman, Ritchhart, Donis, \& Andrade, 2000; D. N. Perkins, Jay, \& Tishman, 1993), although not specific to a knowledge worker context.

\section{How Are Persons with Higher Education Different: A Dispositional View}

In this section, we discuss "acquired or nurtured" individual-difference tendencies that are, in part, an outcome of education effects. Without asserting an exhaustive set of dispositional tendencies, what follows is a discussion of identified dimensions on which group-differences based on education level (knowledge workers versus non-knowledge workers) can be established. The identified dimensions (authoritarianism, ambiguity tolerance, dogmatism, need for closure, and cognitive ability) serves to illuminate how education effects present a new humanistic way of thinking about knowledge workers and how they are different. The distinction between treatment effects and selection effects is a concern among social scientists. Thus, although we ground our discussion in the available evidence, it is hard to distinguish the case of treatment effects for identified dispositions, but there is some support that selection effects are partly responsible for what appears as group differences in cognitive ability or education effects.

\section{Authoritarianism}

Authoritarianism (Bob Altemeyer, 1998) is a personal disposition conceptualized as a syndrome composed of three interrelated attitude clusters: authoritarian submission (a tendency towards uncritical submission to authorities), authoritarian conventionalism (strict adherence to conventional norms and values), and authoritarian aggression (feelings of aggression towards norm violators) (Rattazzi, Bobbio, \& Canova, 2007). A long history of research in political psychology has focused on better understanding the antecedents and consequences of authoritarianism. From its early days, this research has explored the role played by education in reducing the tendency towards authoritarianism. The earlier studies of this issue consistently reported a negative relationship between the level of education and authoritarianism (Kohn, 1969; Lipsitz, 1965; Williams, 1966). It seems that any authoritarian tendencies in an individual were reduced or alleviated as a consequence of attending higher education (e.g. a college). Although subsequent research has shown that the strength level of education effect seems to depend on factor such as the content of the educational program (e.g. which subject major), and national culture (Dekker \& Ester, 1987), the majority of the evidence still supports the existence of a direct negative relationship between level of education and authoritarianism. Hence, we propose that:

Hypothesis 1a. The education level of individuals relates negatively to authoritarian disposition. 


\section{Tolerance for Ambiguity}

Budner (1962) defines tolerance for ambiguity as the tendency to "perceive ambiguous situations as desirable" and intolerance for ambiguity as "the tendency to perceive ambiguous situations as a source of threat." As a personality variable, ambiguity has been associated with positive traits, such as openness to new ideas and originality (Tatzel, 1980). On the other hand, ambiguity intolerance is associated with lower mental flexibility and negative personality traits, such as conformity, mental rigidity, and ethnic prejudice (Weissenstein, Ligges, Brouwer, Marschall, \& Friederichs, 2014, p. 1). This implies that individual-level traits, such as uncertainty orientation, complexity, unfamiliarity and a predisposition to risk-taking are correlates of ambiguity tolerance. In the context of educational psychology, meaningful learning empowers students to gain problem-solving skills (Mayer, 2002; McKeough \& Sanderson, 1996; Phye, 1997) and can solve new and ambiguous problems (Shuell, 1990).

According to (Hauser, 1970), less education and fundamentalist religious affiliations are part of individual characteristics associated with lower tolerance ((Moore \& Ovadia, 2006, p. 2206): 2206). In terms of evidence, there is a consistent positive relationship between an individual's education level and tolerance. (Bobo \& Licari, 1989; Davis, 1975; Dynes, 1967; Hyman \& Wright, 1979; Stouffer, 1963; Weil, 1985; Williams Jr, Nunn, \& Peter, 1976). The positive relationship between an individual's education level and tolerance is one of the most consistently documented results in the empirical research (Bobo \& Licari, 1989; Davis, 1975; Dynes, 1967; Hyman \& Wright, 1979; Stouffer, 1963; Weil, 1985; Williams Jr et al., 1976).

Through education, a tolerance-producing setting is created as individuals are exposed to values and ideas that may differ from those they uphold (Stouffer, 1963):127). Thus, (higher) education increases one's knowledge of diverse cultures, openness to novel ideas, and willingness to risk uncertainty and ambiguity (Moore \& Ovadia, 2006): 2209).

\section{Hypothesis 1b. The education level of individuals relates positively to ambiguity tolerance.}

\section{Dogmatism}

Dogmatism is a stable personal trait that is defined as a relative unchangeable unjustified certainty (Bob Altemeyer, 2002). In The Open and Closed Mind, Rockeach (1990) suggested that dogmatism reflects a deficit in integrating information that threatens multiple prior beliefs into a new belief system. Dogmatism, derived from social psychological theory, is a determinant of closed-mindedness, conformity, myopia, and self-righteousness. Research has shown that more dogmatic individuals show greater persistence of a belief after the evidence that formed the belief has been discredited (Martin F Davies, 1993), and they tend to ignore information that does not support their prior beliefs (Martin F Davies, 1998). Other studies have suggested an association between dogmatism and rigid problemsolving behavior and high resistance to change over the short-term and long-term (Ehrlich \& Bauer, 1966 p. 253).

Educational experiences can broaden an individual's experience base, which encourages an openminded personality to new experiences and consideration of alternative viewpoints and new experiences (Pascarella, Edison, Nora, Hagedorn, \& Terenzini, 1996; Vogt, 1997). As students attain higher levels of education, their beliefs towards learning become more sophisticated and develop a mind richly grounded in intellectual virtues. According to (Schommer, 1990), university students tend to have more sophisticated beliefs than junior college students. Hence, the available evidence supports a negative relationship between higher educated and dogmatism.

Hypothesis 1c. The education level of individuals relates negatively to dogmatism tendencies.

\section{Need for Cognitive Closure}

Need for cognitive closure, or simply need for closure (NFC) is defined as the preference for "an answer to a given topic, any answer compared to confusion and ambiguity" (Arie W Kruglanski, 1990):337). Although the need for closure may vary situationally (Arie W Kruglanski \& Freund, 1983), it also represents a dimension of stable individual differences (Webster \& Kruglanski, 1994): 1050). 
Individuals with high levels of NFC are characterized by strong preferences for order and predictability afforded by stable, secure knowledge that unaffected by circumstances and not challenged by expectations. NFC is associated with a wish to reach firm and swift decisions, a need for decisiveness and a feeling of discomfort with ambiguity (Arie W Kruglanski, 1989, 1990; Richter \& Kruglanski, 1998). They also experience solutions with lack of closure as aversive.

In the course of schooling, students inevitably experience ambiguity or confusion as they encounter challenging instructional tasks. It is especially true for students in secondary education, and higher where knowledge encountered is more likely to be increasingly complex, tentative, or controversial (e.g., DeBacker \& Crowson, 2009; Kuhn, Black, Keselman, \& Kaplan, 2000). Some studies have provided evidence for a positive relationship between need for closure and crystallized knowledge. In terms of evidence, weak to moderate positive correlations have been observed between need for closure and performance in college (e.g.,Cacioppo \& Petty, 1982; Jarvis \& Petty, 1996). Hence, higher education reduces learners' need for closure.

Hypothesis 1d. The education level of individuals relates negatively to their need for closure.

\section{General Intelligence/Cognitive Abilities}

General intelligence ( $\mathrm{g}$ factor) refers to the existence of a broad mental capacity that influences performance on cognitive ability measures (Spearman, 1904). As a broad generalization, individuals high in general intelligence must exhibit domain-independent skills that foreground the presence and effectiveness of cognitive-, and meta- processes (e.g., Baron-Cohen, Leslie, \& Frith, 1985; Carroll, 1993) and skills of thinking and learning, such as brainstorming, searching for evidence, and relating new information to old (D. Perkins, 1995). General intelligence remains relatively stable across the life span (Briley \& Tucker-Drob, 2014)and arguably maintains a mostly similar strength and structure with age (Batterham, Mackinnon, \& Christensen, 2011; Gignac, 2014; Tucker-Drob, 2009).

Education is consistently identified as an intelligence-boosting factor. The scientific case for the association between education and general intelligence (cognitive ability) is well established and report a moderate to strong correlation (e.g., Strenze, 2007). Away from debate on the causal relationship between education and intelligence along with the multiple interpretations (see, for example Deary \& Johnson, 2010), there is consistent evidence supporting the view that education has a positive, causal effect on general intelligence (Ceci, 1991; Ritchie, Bates, \& Deary, 2015; Ritchie \& Tucker-Drob, 2018; Spearman, 1904). A recent meta-analysis study (Ritchie \& Tucker-Drob, 2018) find consistent evidence for the positive effect of schooling on cognitive abilities of approximately 1 to 5 IQ points for an additional year of education. Also, based on moderation analysis, the authors find the effects persisted across the life span and were persistent in all broad categories of cognitive ability studied. Hence, based on the literature reviewed, education appears to be a consistent and robust method identified for raising intelligence.

Hypothesis 1e. The education level of individuals relates positively to their cognitive ability.

\section{Contextual Moderation}

Personality - Environment (Organization) Relationship

As noted above, person-environment interaction models provide frameworks for discussing student change and college effects. With an emphasis on the organizational environment, Strange (2003) views it as systems influenced by organizations' goals, values, activities, which in turn shapes organizational structures. The nature of the environment, thus, depends to some degree on organizations' complexity, centralization, formalization, and hierarchy.

Organizational structures (e.g., degree of centralization) form a basis in the design of units that group individuals, their reporting relationships, and the coordinate mechanism that integrate a unit's activities and resources (Huber, 1991; Moorman, Niehoff, \& Organ, 1993). We draw on the Attraction-SelectionAttrition (ASA) theory (Schneider, 1987) to explain how individuals perceive organizational structures as appropriate and relevant to them. The ASA model is person-based, and grounded in the view that 
organization structures, processes, and culture reflect the collective personality of individuals on a job (Schneider, 1987). The interrelated processes of attraction, selection, and attrition predict organizations as striving for homogeneity; hence, the homogeneity hypothesis: that members of the same unit or organization should be more similar in shared personality than members of different organizations. Assuming the homogeneity holds, it suggests that over time, a workgroup's collective personality will be favorably associated with the organization's structures. Therefore, low (vs. high) degree of centralization should be favorably associated with the identified non-cognitive individual-level dispositions (cross-level direct effect).

H2a. Centralization is related positively to dogmatism.

H2b. Centralization is related positively to authoritarianism.

H2c. Centralization is related positively to need for closure.

H2d. Centralization is related negatively to ambiguity tolerance.

However, organization structure perceptions will not result in the homogenization of traits within the organization or workgroups if perceptions of the structure are idiosyncratic, subjective phenomena (Schaubroeck, Ganster, \& Jones, 1998). There are instances individuals find themselves in particular workgroups or organizations for reasons independent of the ASA theory. Quitting one's dissatisfying job is often a more complicated and challenging endeavor that it would appear to be. Such factors, including alternative employment availability and family concerns, for example, are constraints that may limit turnover, thus continuing tenure at an organization. Also, high-tenure individuals may have accumulated more sunk costs, or investments with the organization (Becker, 1960; Meyer \& Allen, 1984), making it difficult to leave the organization regardless of organizational structures.

As such, individuals may be more attentive or responsive to organizational structures. It conceivably follows that this inconsistency would be particularly pronounced for those individuals who have been in their work positions for several years. It is our position; therefore, that being unwilling or unable to leave a dissatisfying workplace situation is likely to be more difficult and frustrating for individuals with high education, bent on autonomy, self-actualization, and creative behavior and uncomfortable with centralization, than for those who are indifferent and inert with low education. Therefore, we assert that the interaction between education and structures (i.e., centralization) may result in divergent complex behaviors depending on the individual's tenure on the job (cross-level interactive effects). Given the generally weak theoretical and empirical foundation, we did not formulate specific personality-situation relationships.

Hypothesis 3. Education and centralization interact: the relationship between education and personality is weaker in a centralized organizational structure.

\section{Moderating Role of Age}

Thus far, we have suggested that education is associated with some individual-level dispositions dogmatism, need for closure, authoritarianism, ambiguity tolerance, and cognitive closure. The developmental theories, especially the psychosocial theories, partly attribute student development to age progression. Research on personality and aging (e.g., Caspi \& Roberts, 2001; McCrae \& Costa Jr, 1994; Roberts, Walton, \& Viechtbauer, 2006)reflect a set of characteristic dispositions that determine emotional, interpersonal, experiential, attitudinal and motivational styles. The central issue concerns the extent to which aging processes are responsible for personality change.

Deep level personality changes in adulthood were, for a long time, a controversial issue among psychologists. The classical view held by psychoanalysts (Freud, 1923; Sapir, 1934) was up until recently that personalities were formed in early years and remained virtually unchanged throughout the subsequent life span. For example, Sapir (1934) explicitly claimed that personality was formed by the age two or 
three. Freud (1923) argued that identity, ego, and superego were fully developed around age five. Bloom (1964) argued that there was "rapid personality development in the early years of infancy and childhood, the possibility of marked changes in the adolescent period, and the likelihood of small changes during adulthood and maturity" (p. 132-133). However, these earlier students of personality development have little empirical evidence to back up their claims, as very few longitudinal studies had been carried out. Now, and partly based on longitudinal evidence, one consensus is that personality is developing until the age of 30, coinciding with the current view on when the developmental stage of adulthood begins (McCrae \& Costa Jr, 1994). In a more recent review of the research evidence, Caspi and Roberts (2001) concluded, "evidence indicates that personality appears to grow increasingly consistent with age to reach a plateau later in life than originally thought (e.g., 50 years). Furthermore, life experiences appear to be related to individual differences in personality change well into the $4^{\text {th }}$ decade of life" $(\mathrm{p}$. 51). Their conclusion is also supported by meta-analyses of more than 90 longitudinal studies of how changes in mean scores on the "Big five" personality traits are related to age (Roberts et al., 2006). Hence, available evidence does not contradict the idea that personal growth experience leads to deep level changes. Differently stated, education and aging, both have a prominent role in an individual's growth process leading to changes in traits that are often seen as crystallized and non-changeable -or the very defining properties of the individual.

Conceptualizing age to account for the personal growth process away from education experiences, the role of other life experiences may dilute the effects of the educational experience. For young individuals, life experiences away from schooling are limited compared to older individuals who are involved in many social, political, and corporate endeavors. These arguments lead us to advance an interactive prediction regarding how aging shape the association between education and personality. Therefore, we propose that age dilutes the effect of education on the constellation of personality dispositions already outlined above.

H4a. Age moderates the education-dogmatism relationship, such that the effect is weaker for aged compared to younger individuals.

H4b. Age moderates the education-need for closure relationship, such that the effect is weaker for aged compared to younger individuals.

H4c. Age moderates the education-authoritarianism relationship, such that the effect is weaker for aged compared to younger individuals.

H4d. Age moderates the education-ambiguity tolerance relationship, such that the effect is weaker for aged compared to younger individuals.

\section{METHODS}

\section{Sample and Procedures}

A total of 351 employees in 54 workgroups completed the survey for a response rate of 55\%. Participants were full-time employees at two organizations (one public enterprise and one large private multinational) in Ghana. The public enterprise operates in the energy sector and is the largest electricity service provider in the country. Data for this study were collected via administering questionnaires during organizations' work time (i.e., lunch shifts). Using a unique identifier, this data set was linked with organizational administrative records, which identified each participant's workgroup, higher entities (i.e., unit, department, division), and immediate leader/supervisor. A workgroup is the smallest core entity in these organizations, consisting of members and their immediate supervisor/leader. For many of the workgroups, members have different responsibilities, yet, share a common goal.

The average workgroup size is 6.5 members, with only two workgroups having a single member. Thirty-four percent of the respondents were female. The average positional tenure was seven years and five years respectively. The age of respondents ranged from 15 to 78 (mean $=36$; standard deviation $=$ 10.56). The respondents' jobs varied from manual labor through clerical to the executive, in such diverse 
settings as drivers, stores officer, procurement, operations, administration, sales and customer relations, purchasing clerk, engineering, insurance, and accountants. All respondents were informed that their responses would be confidential and used only for research purposes.

\section{Measures}

For all measures excluding education and cognitive ability, participants responded on a five-point Likert-type scales ranging from " $1=$ strongly disagree" to " $5=$ strongly agree", unless otherwise stated. All scales were adopted from established measures. Before computing composite scales, exploratory principal components analysis was used on all the multi-item scales to determine item retention. All scales satisfied Bartlett's test for sphericity (correlation matrix test) and the Kaiser-Meyer-Olkin (KMO) measure of sampling adequacy criterions for factorability.

\section{Authoritarianism}

Authoritarianism was assessed using seven items (counter-balanced) from Zakrisson (2005) short version of the Right-Wing Authoritarianism scale. Sample items are "Our society would be better off if we showed tolerance and understanding for untraditional values and opinions" and "Our country needs free thinkers, who will have the courage to stand up against traditional ways, even if this upsets the people." The coefficient alpha of the authoritarianism scale was .79.

\section{Cognitive Ability}

Cognitive ability was measured with a three-item Cognitive Reflective Test that Frederick (2005) developed and validated. A composite scale is computed as the total number of correct answers on the test.

\section{Need for Closure}

We followed Webster and Kruglanski (1994) and operationalized the need for closure as affective discomfort occasioned by ambiguity. Nine items were used. Sample items are "I feel uncomfortable when someone's meaning or intention is unclear to me" and "When I am confused about an important issue, I feel upset." The coefficient alpha of the need for closure scale was .84.

\section{Ambiguity Tolerance}

We measured ambiguity tolerance using Kirton (1981) reduced the 7-item scale from the Budner (1962) original 16-item scale of tolerance-intolerance of ambiguity. These 7-items reflect three subdimensions: novelty, complexity, and insolubility. Sample items are "An expert who does not come up with a definite answer probably does not know too much" and "A good job is one where what is to be done and how it is to be done are always dear." The coefficient alpha was .80.

\section{Dogmatism}

We followed Troldahl and Powell (1965) short form of Rokeach dogmatism scale. Troldahl and Powell suggested that "a researcher who wishes to use a short form of the dogmatism scale needs only to decide how many items he can use. He should then select the first " $n$ " items in the Table 1 as the best set of items to use" (1965:214). Hence, the construct is operationalized with the first five items. Sample items are "In this complicated world of ours, the only way we can know what is going on is to rely on leaders or experts who can be trusted" and "My blood boils whenever a person stubbornly refuses to admit he is wrong." The reduced form scale showed reasonable internal consistency (coefficient alpha was .73).

\section{Education}

We measure respondents' highest education level attained. The highest attained education level ranged from primary to post-graduate degrees (e.g., MSc, Ph.D.). Their years of schooling ranged from 6 to 25 , with the largest percentage (52\%) stopping their education at the end of college (i.e., 4years degree), and the next largest percentage (20.8\%) at the end of high school.

Control Variables 
Guided by the theoretical framework and review of the relevant literature discussed above, we controlled for demographics (i.e., age, gender, and tenure) and work-related characteristics (i.e., job autonomy and organizational structures such as degree of centralization). Job characteristics scale comprise sub-dimensions as autonomy, skill variety, task identity, task significance, and feedback about results were measured with the Job Diagnostic Survey (Hackman \& Oldham, 1975). Internal consistency is $.80(.72)$. The degree of centralization was assessed using a five-item hierarchy of the authority scale (Hage \& Aiken, 1967; Hage \& Aiken, 1970). It is intended to measure the degree to which organization members participate in decisions involving the tasks associated with their position (Pennings, 1973: 689). Cronbach's alpha is .83.

\section{RESULTS}

\section{Measurement Model and Response Bias Checks}

Before testing our hypothesis, we ran a confirmatory factor analysis (CFA) for our measures. We run a series of CFAs for our measures of centralization and the outcome variables (ambiguity tolerance, dogmatism, authoritarianism, and need for closure). The final measurement model fits fairly well: $\mathrm{RMSEA}=.062, \mathrm{CFI}=.866$, and $\mathrm{SRMR}=.054$. According to $\mathrm{Hu}$ and Bentler (1999), it is often sufficient to rely on SRMR and one of the remaining indexes (i.e., RMSEA, CFI, or NNFI). Thus, our finding is satisfactory under $\mathrm{Hu}$ and Bentler (1999) interpretation of fit indexes. All constructs have reliability above .7, which are satisfactory (Nunnally, 1978). "Discriminant validity is achieved if the correlations between factors are less than 1.00 by an amount greater than two standard errors" (Xie, Bagozzi, \& Grønhaug, 2015: 344). Our measurement fulfills this condition of discriminant validity. All factor loadings were significant and ranged from .52 to .87 .

All personality measures, education, and control variables were accessed at the same time. This research design raises concerns about common method bias (note that this concern is not relevant to the education-personality relationships). Harman's single factor test showed more than a one-factor solution, which seems to suggest that common method bias may not be a problem. Scale items were averaged to form composite variables.

\section{Hypothesis Tests}

Descriptive statistics, bivariate correlations, and scale reliabilities are presented in Table 1. Table 1 reveals a statistically significant medium to high correlations ranging from .15 to .67 in absolute terms among the five personality traits under study. The correlations between educational level on one hand and dogmatism, need for closure, ambiguity tolerance, authoritarianism, and cognitive ability, on the other hand, were all significant $(p<.05)$. Age, gender, positional tenure, degree of centralization, job autonomy were found to have many significant relationships with the personality trait variables. Hence, we controlled for age, gender, positional tenure, degree of centralization, job autonomy and a dummy variable to account for organization-specific differences for our analyses.

We expect education to predict or explain in different ways, the set of personality dispositions outlined. We conducted a multivariate analysis of variance (MANOVA) using personality constructs as dependent variable and education as a categorical independent variable. Table 2 report MANOVA results were statistically significant, and intraclass correlation ICC(1) values were greater than .12. That is, the two views on education and set of personality traits are closely related: the best linear combination of the personality traits is correlated at almost 0.60 with the best linear combination of education. All the associated tests were significantly rejecting the null hypothesis that the two sets of variables are not linearly related. Also, the effect sizes (ICC's) indicate a fairly substantial clustering in the data at the work-group level. These results suggest that ambiguity tolerance, dogmatism, need for closure, authoritarianism, and cognitive ability distinguish between individuals within workgroups.

To account for the nested nature of data with varying sample sizes within workgroups, we conducted our analysis using random coefficient models (Aguinis, Gottfredson, \& Culpepper, 2013; Raudenbush \& Bryk, 2002) to estimate the association between the education predictor on the multiple level 1 personality trait outcomes. 


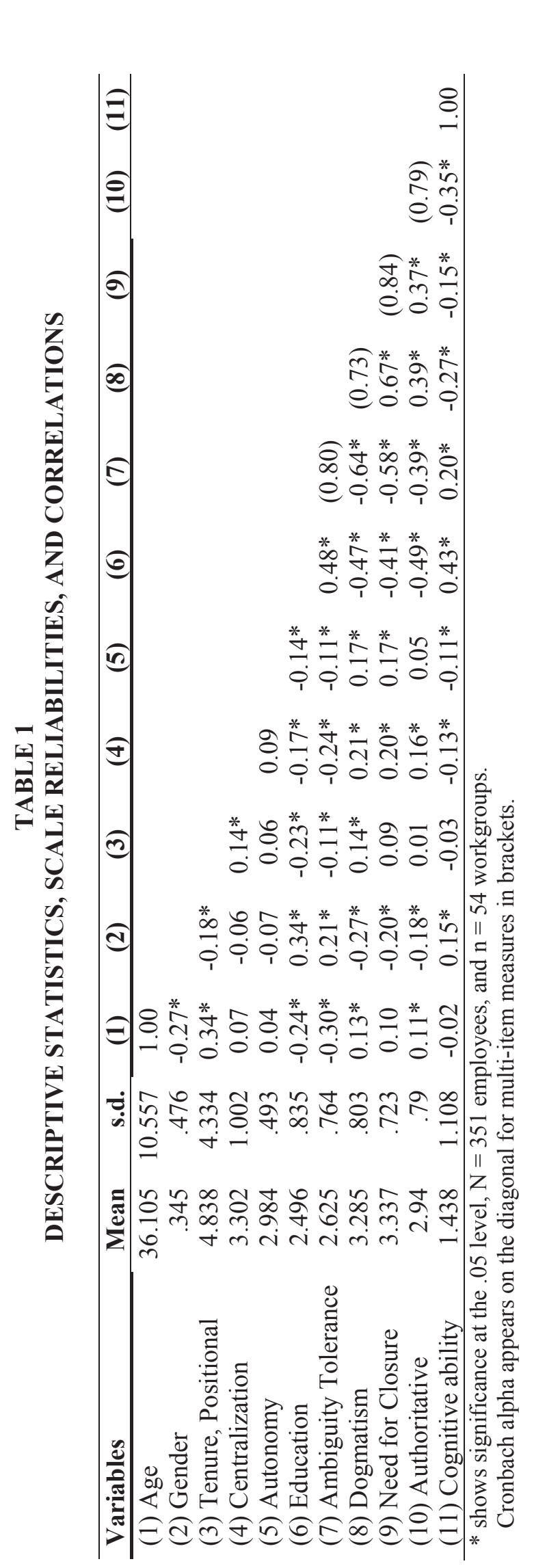


TABLE 2

INTRACLASS CORRELATION AND MANOVA AT INDIVIDUAL LEVEL

\begin{tabular}{lcc}
\hline Variable & ICC(1) & Squared canonical Correlation \\
\hline Ambiguity tolerance & .32 & .60 \\
Dogmatism & .28 & .15 \\
Need for closure & .23 & .04 \\
Authoritarianism & .31 & \\
Cognitive ability & .41 & \\
Wilk's $\lambda$ & $.58 * * *$ & \\
$* * * p<.001$ &
\end{tabular}

The regression analyses are shown in Table 3. We tested our hypotheses using the RCM, which group-mean centered Level 1 predictors except for the dichotomized gender variable coded 0 for men and 1 for women. Following recommendations, Level 2 variables are grand-mean centered (Hofmann \& Gavin, 1998). First, hypotheses 1a-1e relate education to individual-level personality dispositions. There was a significant hierarchical effect of education level on ambiguity tolerance, dogmatism, need for closure, authoritarianism, and cognitive ability such that, the higher the level of education, the stronger the effect [in absolute terms]. The findings support our proposition that highly educated individuals (knowledge workers) exhibit traits that are, on average different from those without higher education. Our results supporting hypothesis 1a-1e contributes to the literature by presenting initial evidence to support conceptualizing knowledge workers as highly educated individuals who exhibit individual differences dispositional tendencies that distinguish them from persons low on education (non-knowledge workers).

Hypothesis $2 \mathrm{a}-2 \mathrm{~d}$, that degree of centralization has a cross-level direct effect on traits, is also supported, as shown in Table 3. Hypothesis $4 \mathrm{a}-4 \mathrm{~d}$ predicts that the relationships between education and each personality trait are moderated by Age. We test whether the strength of the education to personality mechanism is dependent on age such that relationships would be weakened when employees are aged (higher in Age). For ease of interpretation and to accommodate the relatively small sub-sample size of educated individuals above a 4-year bachelor's degree, we dichotomize the education variable coded 1 for higher education holders and 0 otherwise. As reported in Models 1, 3, 5 and 7 of Table 4, Age moderated the relationship between education and ambiguity tolerance $(\gamma=.02, p<.01)$, need for closure $(\gamma=-.02, p$ $<.01)$ and Authoritarianism $(\gamma=-.02, p<.01)$. However, the cross-level interaction effect of Hypothesis 3 reported in Table 4 was not supported for all the relationships between education and each personality trait.

We present the significant interaction results in Figures 1, 2, and 3. Figure 1 shows that among the older employees, education level is more positively associated with ambiguity tolerance. In Figure 2, Age boosts the negative relationship between education and personal need for closure. As shown in Figure 3, age strengthens the negative relationship between education and authoritarian tendencies. 
TABLE 3

RANDOM COEFFICIENT MODELING RESULTS

\begin{tabular}{|c|c|c|c|c|c|}
\hline & $\begin{array}{l}\begin{array}{l}\text { Ambiguity } \\
\text { Tolerance }\end{array} \\
(1)\end{array}$ & $\frac{\text { Dogmatism }}{(2)}$ & $\begin{array}{c}\text { Need for } \\
\text { Closure }\end{array}$ & $\frac{\text { Authoritarianism }}{(4)}$ & $\begin{array}{c}\begin{array}{c}\text { Cognitive } \\
\text { Ability }\end{array} \\
(5)\end{array}$ \\
\hline Intercept & $\begin{array}{l}1.51^{* * *} \\
(0.19)\end{array}$ & $\begin{array}{c}4.17^{* * *} \\
(0.19)\end{array}$ & $\begin{array}{l}4.13^{* * * *} \\
(0.19)\end{array}$ & $\begin{array}{l}3.63^{* * *} \\
(0.22)\end{array}$ & $\begin{array}{l}1.25^{* * *} \\
(0.32)\end{array}$ \\
\hline $\begin{array}{l}\text { Secondary } \\
\text { education }\end{array}$ & $\begin{array}{l}0.56^{* * *} \\
(0.12)\end{array}$ & $\begin{array}{l}-0.27^{*} \\
(0.13)\end{array}$ & $\begin{array}{l}-0.13 \\
(0.12)\end{array}$ & $\begin{array}{l}-0.36^{* *} \\
(0.13)\end{array}$ & $\begin{array}{l}0.81^{* * *} \\
(0.19)\end{array}$ \\
\hline $\begin{array}{l}\text { Tertiary, } \\
\text { B.A/BSc }\end{array}$ & $\begin{array}{l}0.99^{* * *} \\
(0.12)\end{array}$ & $\begin{array}{c}-0.78^{* * *} \\
(0.13)\end{array}$ & $\begin{array}{c}-0.66^{* * *} \\
(0.12)\end{array}$ & $\begin{array}{c}-0.88^{* * *} \\
(0.14)\end{array}$ & $\begin{array}{l}0.91^{* * *} \\
(0.19)\end{array}$ \\
\hline $\begin{array}{l}\text { Post tertiary } \\
\mathrm{MA} / \mathrm{MSc} / \mathrm{PhD}\end{array}$ & $\begin{array}{l}1.43^{* * *} \\
(0.17)\end{array}$ & $\begin{array}{c}-1.25^{* * *} \\
(0.17)\end{array}$ & $\begin{array}{c}-1.12^{* * *} \\
(0.18)\end{array}$ & $\begin{array}{c}-1.20^{* * *} \\
(0.18)\end{array}$ & $\begin{array}{l}1.10^{* * *} \\
(0.25)\end{array}$ \\
\hline Age & $\begin{array}{c}-0.01^{* * *} \\
(0.00)\end{array}$ & $\begin{array}{l}-0.00 \\
(0.00)\end{array}$ & $\begin{array}{l}-0.00 \\
(0.00)\end{array}$ & $\begin{array}{c}0.00 \\
(0.00)\end{array}$ & $\begin{array}{c}0.01 \\
(0.01)\end{array}$ \\
\hline Gender & $\begin{array}{c}0.01 \\
(0.07)\end{array}$ & $\begin{array}{l}-0.21^{*} \\
(0.08)\end{array}$ & $\begin{array}{l}-0.08 \\
(0.08)\end{array}$ & $\begin{array}{l}-0.03 \\
(0.08)\end{array}$ & $\begin{array}{c}0.12 \\
(0.11)\end{array}$ \\
\hline Autonomy & $\begin{array}{l}-0.03 \\
(0.07)\end{array}$ & $\begin{array}{c}0.07 \\
(0.08)\end{array}$ & $\begin{array}{c}0.06 \\
(0.08)\end{array}$ & $\begin{array}{l}-0.03 \\
(0.08)\end{array}$ & $\begin{array}{l}-0.22^{*} \\
(0.11)\end{array}$ \\
\hline $\begin{array}{l}\text { Tenure, } \\
\text { positional }\end{array}$ & $\begin{array}{l}0.03^{* * *} \\
(0.01)\end{array}$ & $\begin{array}{l}-0.00 \\
(0.01)\end{array}$ & $\begin{array}{l}-0.01 \\
(0.01)\end{array}$ & $\begin{array}{l}-0.02^{*} \\
(0.01)\end{array}$ & $\begin{array}{c}0.01 \\
(0.01)\end{array}$ \\
\hline Centralization & $\begin{array}{c}-0.12^{* * *} \\
(0.03)\end{array}$ & $\begin{array}{l}0.11^{* *} \\
(0.04)\end{array}$ & $\begin{array}{l}0.11^{* *} \\
(0.03)\end{array}$ & $\begin{array}{l}0.08^{*} \\
(0.04)\end{array}$ & $\begin{array}{l}-0.07 \\
(0.05)\end{array}$ \\
\hline $\begin{array}{l}\text { Organization, } \\
\text { private }\end{array}$ & $\begin{array}{l}0.30^{* *} \\
(0.10)\end{array}$ & $\begin{array}{l}-0.21^{*} \\
(0.10)\end{array}$ & $\begin{array}{l}-0.25^{*} \\
(0.10)\end{array}$ & $\begin{array}{l}-0.05 \\
(0.12)\end{array}$ & $\begin{array}{l}-0.43^{*} \\
(0.18)\end{array}$ \\
\hline
\end{tabular}

Standard errors in parentheses. Reference category for education dummy coding is primary school and below. Reference category for organization dummy coding is public enterprise. $\mathrm{N}=354$ and small $\mathrm{n}=54$ work-groups. ${ }^{*} p<$ $0.05,{ }^{* *} p<0.01,{ }^{* * *} p<0.001$ 


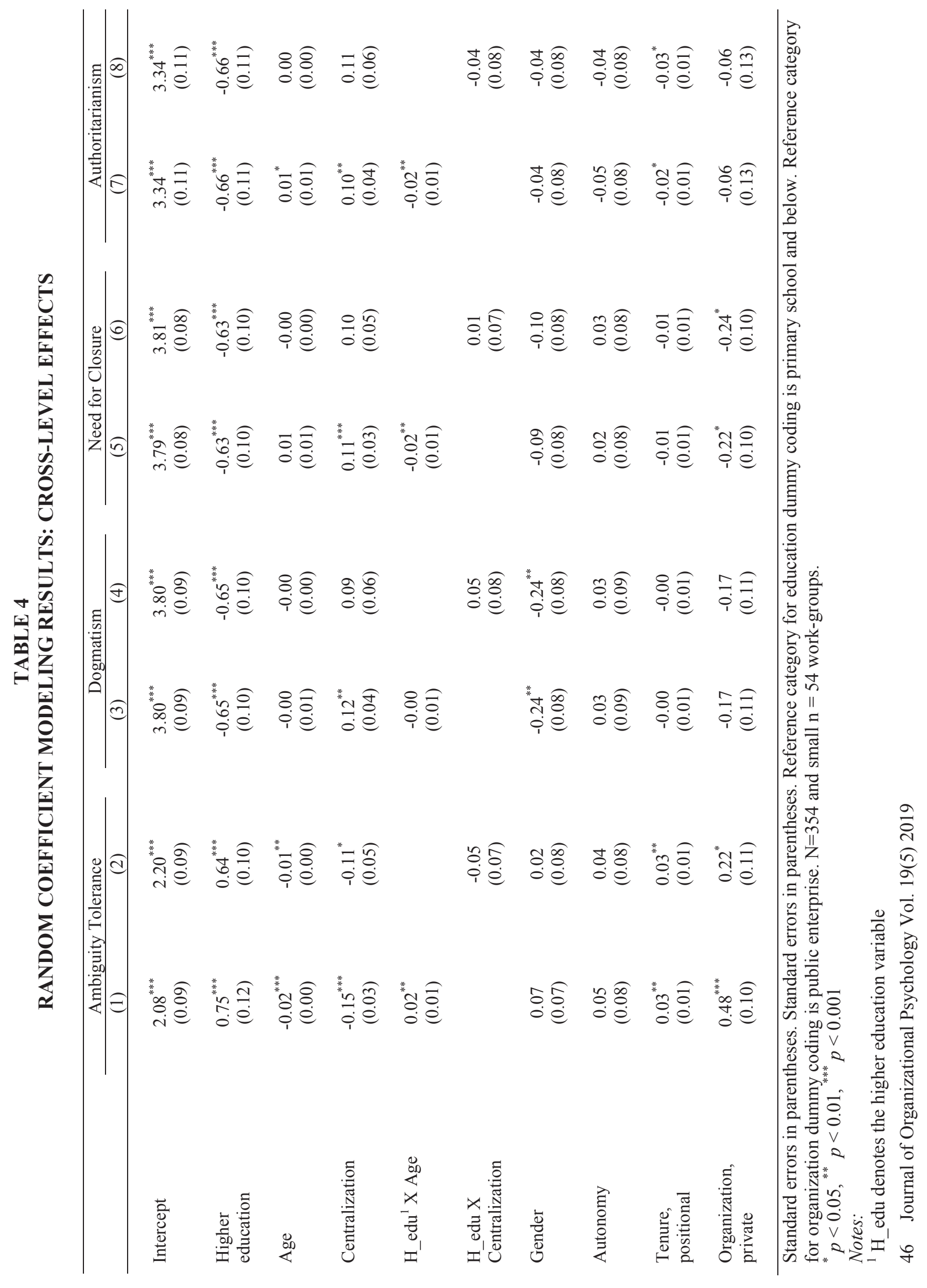




\section{FIGURE 1}

\section{EFFECT OF AGE AND EDUCATION ON AMBIGUITY TOLERANCE}

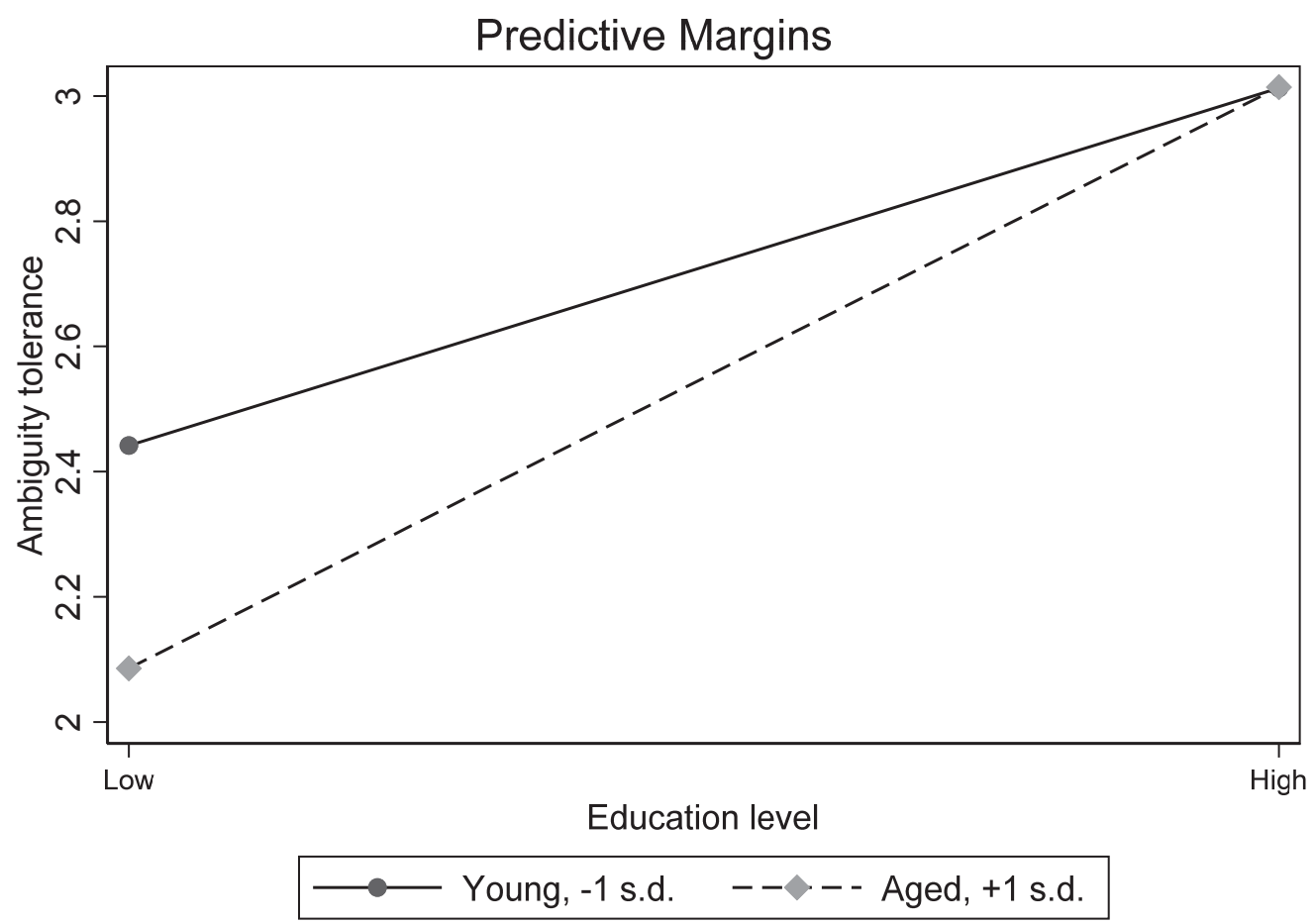

FIGURE 2

EFFECT OF AGE AND EDUCATION ON NEED FOR CLOSURE

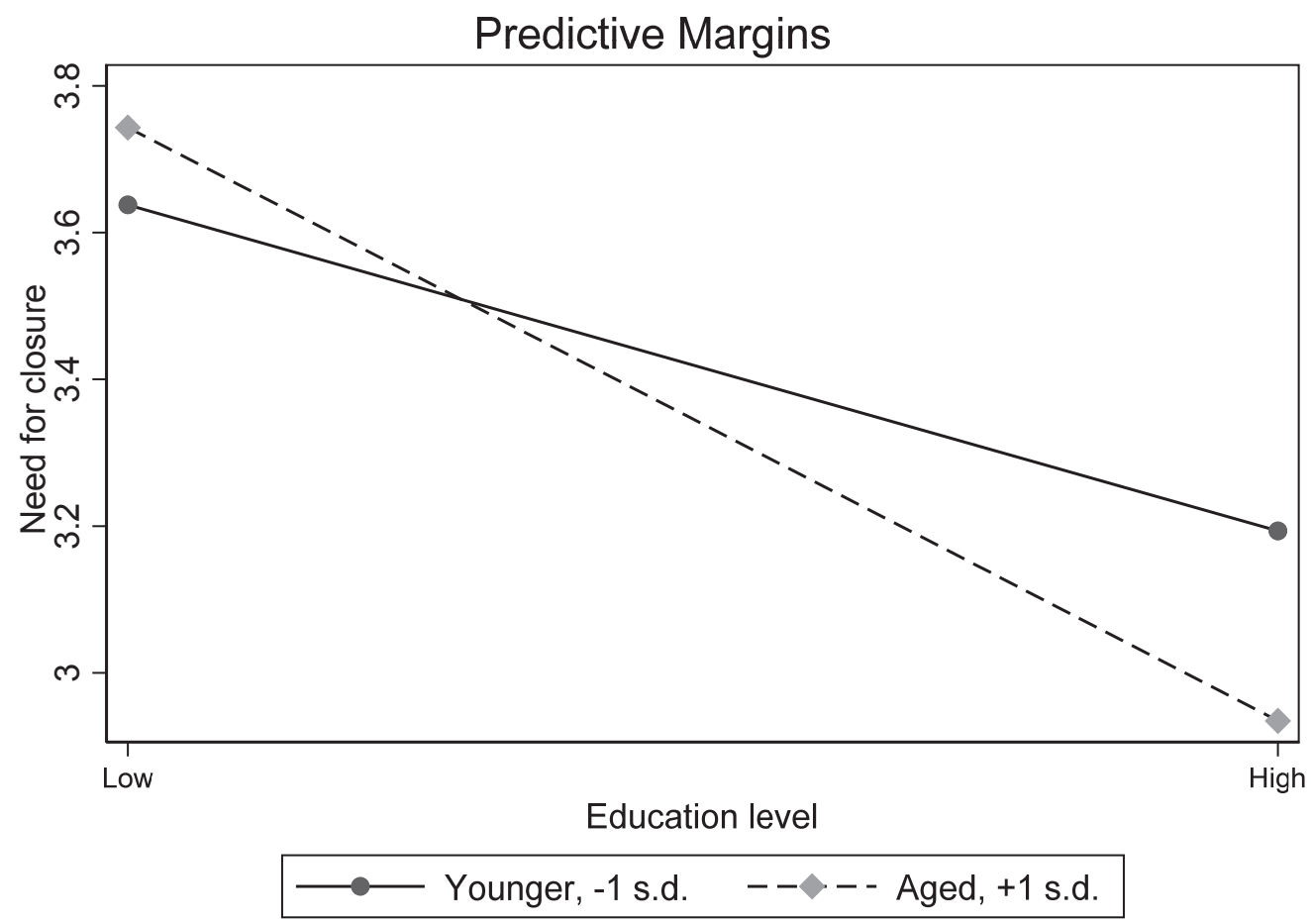


FIGURE 3

EFFECT OF AGE AND EDUCATION ON AUTHORITARIANISM

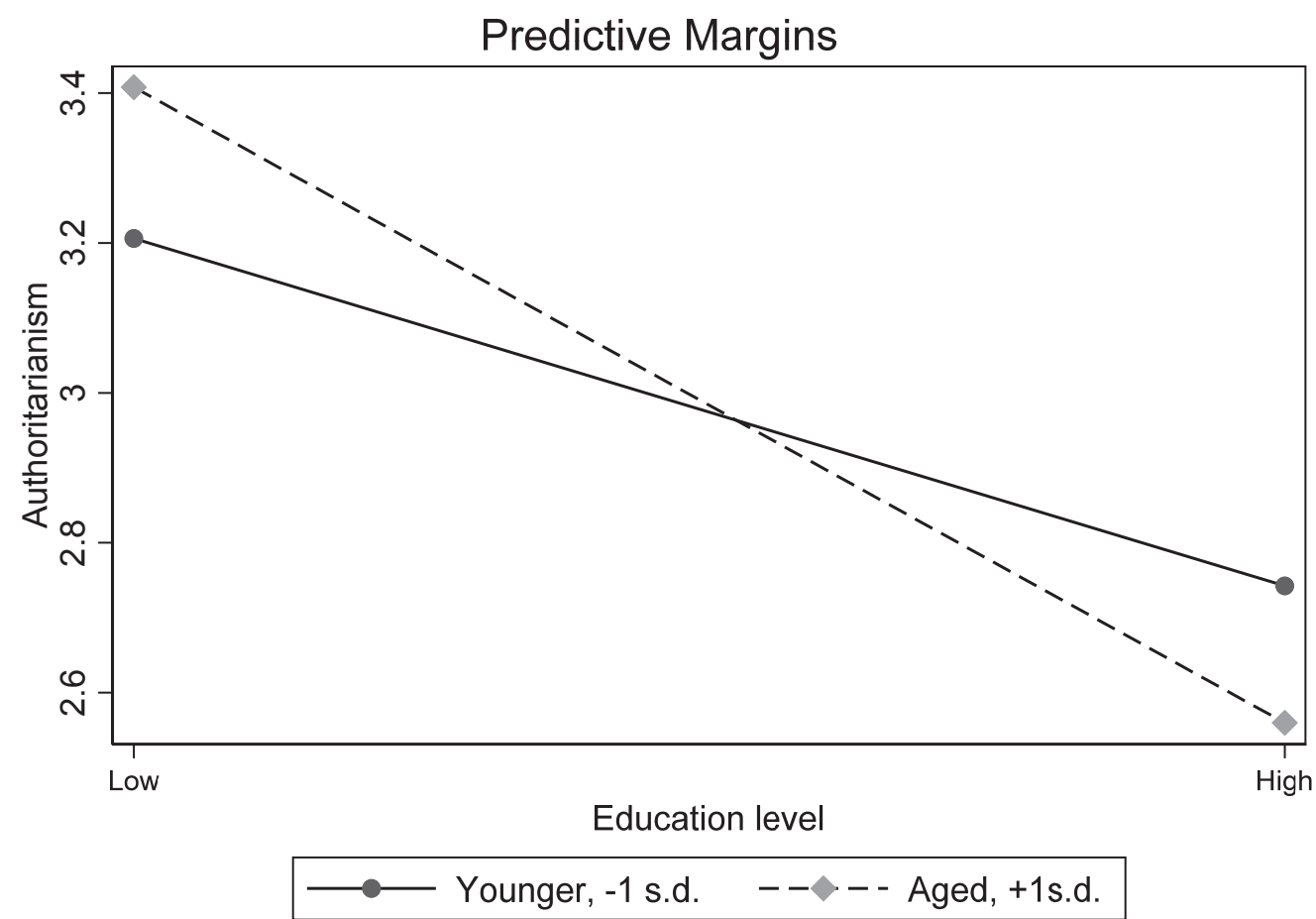

\section{DISCUSSION}

We integrated development theories of student change and multilevel analysis to explicate dispositional-like individual-difference and 'images' characteristic of knowledge workers. This study contributes to a deeper understanding of the knowledge workers and how they are different. We theorized that knowledge workers, defined as highly educated individuals, are predisposed to some common constellation of personality traits and behaviors that accrue partly as an outcome of college effects. This study identified five nurtured traits: dogmatism, ambiguity tolerance, authoritarianism, need for closure, and cognitive ability. RCM supports a statistically significant positive association between education level and ambiguity tolerance and cognitive ability and a significant negative association between education level and dogmatism, authoritarianism, and need for closure.

Findings on the interaction effects support the moderating role of age in the relationship between education and ambiguity tolerance, the need for closure, and authoritarianism. Age reinforced the association between education level and the employees' trait tendencies. However, the moderating role of centralized organizational structure on the relationship between education and each identified individuallevel personality difference was not significant. The findings on age and centralization seem to suggest that we cannot expect the identified nurtured personality traits associated with highly educated individuals (i.e., knowledge workers) to change. Hence, provides evidence that fortifies the stability in acquired traits.

Lastly, compared to public enterprise, dogmatism, ambiguity tolerance, and need for closure were significantly but marginally lower among employees in the private organization. Authoritarianism and cognitive ability were not statistically different between the two organizations. Also, gender was not a significant variable in the models. 


\section{Implications for Theory and Research}

We developed and tested theoretical and empirical propositions explicating a dispositional-like view to distinguish knowledge workers from other groups of workers. A multilevel study of employees supported our prediction that a common constellation of personality traits associated with highly educated individuals to distinguish them from individuals similar, but without (higher) education. A novel contribution of our work is the introduction of a theoretical model that elucidates psychosocial changes inherent in knowledge workers. Although we draw on the educational psychology literature, a field that has partly focused on the global effects of education, this study constitutes a new way of thinking about knowledge workers within the management field.

Our findings on age and centralization suggest stability in acquired traits and provide a context for leadership adaptation. Conceptualizing knowledge workers based on this study, a general implication for effective leadership adaptation can be grounded in the literature on situational leadership theory and contingency theory of leadership. Proposed by Hersey and Blanchard $(1969 ; 1977)$, situational leadership theory is intuitively appealing, seemingly applicable to a wide range of leadership settings, and inherently recognizes that there is no single "best" style of leadership. Effective leadership is thus, contingent on adapting to the abilities and willingness (performance readiness) of individuals or groups that leaders are attempting to influence. Beyond the prescriptive nature of interactions of leader styles and followers attributes offered by the literature on situational leadership theory, the guidelines for interpersonal relations will require leadership theory to foreground the "images" of knowledge workers and its implication for their preferences and responses to leadership.

Another significant contribution of our research is that it expands understanding of the role of organizational structures and aging as a predictor (moderators) in shaping employees' personality dispositions. Other studies have documented relationships between personality traits and organizational structures. However, our model and empirical findings go beyond previous research by demonstrating the relationship in the context of knowledge workers and acquired traits as an outcome of college effects.

\section{Practical Implications}

The study findings have a significant impact on management in knowledge-based organizations. Now more than ever, the knowledge economy has significantly increased reliance on a highly educated workforce to achieve primary management task of value creation to gain organizational competitive advantage. This new wave of global economic restructuring prompts a management concern to explore new pathways to manage knowledge workers effectively. This study offers that crucial first step and shows how knowledge workers can be thought to differ from other groups of workers. Management must, therefore, understand individual-difference dispositional tendencies that commonly characterize their knowledge workers because their behaviors, values, and norms can have substantial action consequences, which can be linked to positive or negative responses that workers take towards the organization.

\section{Limitations and Future Research Directions}

Although we touch on a limited set of dispositions, it is fair to say that research in individual differences tradition focused on personality has resulted in significant differences in the number and levels of the individual-difference dispositions, given (higher) education. Albeit, they are more similar than dissimilar in spirit, emphasizing tendencies primarily on such as open-mindedness, tolerance of ambiguity, moral competence, need for closure, and political liberalism. In future research, one can examine how the common constellation of traits unique to knowledge workers inform their preferences for and responses to leadership, human resource management, practices, and other organizational management systems.

Also, we gathered the survey data from the energy and service trading sectors in a medium developed country (Ghana). For future research avenues, it would be interesting to see how these results compared to similar industries in other countries in the region and the world, as well as whether or not the level of a country's world economic and socio-cultural stature has any impact on the strength of the findings. 


\section{REFERENCES}

Aguinis, H., Gottfredson, R. K., \& Culpepper, S. A. (2013). Best-practice recommendations for estimating cross-level interaction effects using multilevel modeling. Journal of Management, 39(6), 1490-1528.

Altemeyer, B. (1998). The other "authoritarian personality" Advances in experimental social psychology (Vol. 30, pp. 47-92): Elsevier.

Altemeyer, B. (2002). Dogmatic behavior among students: Testing a new measure of dogmatism. The Journal of Social Psychology, 142(6), 713-721.

Alvesson, M. (2001). Knowledge Work: Ambiguity, Image and Identity. Human Relations, 54(7), 863886. doi:10.1177/0018726701547004

Astin, A. W. (1984). Student involvement: A developmental theory for higher education. Journal of College Student Personnel, 25(4), 297-308.

Astin, A. W. (1985). Achieving educational excellence. Jossey-Bass.

Baron-Cohen, S., Leslie, A. M., \& Frith, U. (1985). Does the autistic child have a "theory of mind"? Cognition, 21(1), 37-46.

Batterham, P. J., Mackinnon, A. J., \& Christensen, H. (2011). The effect of education on the onset and rate of terminal decline. Psychology Aging, 26(2), 339.

Beaumont, P. B., \& Hunter, L. C. (2002). Managing knowledge workers: The HR dimension. Chartered Institute of Personnel and Development.

Becker, H. S. (1960). Notes on the concept of commitment. American Journal of Sociology, 66(1), 32-40.

Bell, D. (1973). The coming of the post-industrial society. Paper presented at the The Educational Forum.

Bell, D. (1979). The new class: a muddled concept. Society, 16(2), 15-23.

Bettis, R. A., \& Hitt, M. A. (1995). The new competitive landscape. Strategic Management Journal, 16(S1), 7-19.

Blair, T. (1998). The third way: new politics for the new century (Vol. 7). London: Fabian Society

Bloom, B. S. (1964). Stability and change in human characteristics. Wiley.

Bobo, L., \& Licari, F. C. (1989). Education and political tolerance: Testing the effects of cognitive sophistication and target group affect, 53(3), 285-308.

Briley, D. A., \& Tucker-Drob, E. M. (2014). Genetic and environmental continuity in personality development: A meta-analysis. Psychological Bulletin, 140(5), 1303.

Budner, S. (1962). Intolerance of ambiguity as a personality variable. Journal of Personality, 30(1), 2950.

Cacioppo, J. T., \& Petty, R. E. (1982). The need for cognition. Journal of Personality Social Psychology, $42(1), 116$.

Carroll, J. B. (1993). Human cognitive abilities: A survey of factor-analytic studies. Cambridge University Press.

Caspi, A., \& Roberts, B. W. (2001). Personality development across the life course: The argument for change and continuity. Psychological Inquiry, 12(2), 49-66.

Ceci, S. J. (1991). How much does schooling influence general intelligence and its cognitive components? A reassessment of the evidence. Developmental Psychology, 27(5), 703.

Chickering, A. W. (1969). Education and identity. Jossey-Bass San Francisco.

Choi, T. Y., \& Varney, G. H. (1995). Rethinking the knowledge workers: Where have all the workers gone? Organization Development Journal, 13(2), 41-50.

Conner, K. R., \& Prahalad, C. K. (1996). A resource-based theory of the firm: Knowledge versus opportunism. Organization Science, 7(5), 477-501.

Darr, A., \& Warhurst, C. (2008). Assumptions, Assertions and the Need for Evidence Debugging Debates about Knowledge Workers. Current Sociology, 56(1), 25-45.

Davenport, T. H., Thomas, R. J., \& Cantrell, S. (2002). The mysterious art and science of knowledge worker performance. MIT-Sloan-Management-Review, 44(1), 23-30. 
Davies, M. F. (1993). Dogmatism and te Persistence of Discredited Beliefs. Personality Social Psychology Bulletin, 19(6), 692-699.

Davies, M. F. (1998). Dogmatism and belief formation: Output interference in the processing of supporting and contradictory cognitions. Journal of Personality Social Psychology, 75(2), 456.

Davis, J. A. (1975). Communism, conformity, cohorts, and categories: American tolerance in 1954 and 1972-73. American Journal of Sociology, 81(3), 491-513.

Deary, I. J., \& Johnson, W. (2010). Intelligence and education: causal perceptions drive analytic processes and therefore conclusions. International Journal of Epidemiology, 39(5), 1362-1369.

DeBacker, T. K., \& Crowson, H. M. (2009). The influence of need for closure on learning and teaching. Educational Psychology Review, 21(4), 303-323.

Dekker, P., \& Ester, P. (1987). Working-class authoritarianism: a re-examination of the Lipset thesis. European Journal of Political Research, 15(4), 395-415.

Drucker, P. F. (1959). The Landmarks of Tomorrow. New york: Harper \& Row.

Drucker, P. F. (1993). Post-capital society (Vol. 109). New York: Harper\& Collins.

Drucker, P. F. (1999). Management challenges for the twenty-first century. Oxford, UK: ButterworthHeinemann, 999, 1.

Dynes, W. (1967). Education and tolerance: An analysis of intervening factors. Social Forces, 46(1), $22-$ 34.

Ehrlich, H. J., \& Bauer, M. L. (1966). The correlates of dogmatism and flexibility in psychiatric hospitalization. Journal of Consulting Psychology, 30(3), 253.

Ennis, R. (1991). Critical thinking: A streamlined conception. Teaching Philosophy, 14(1), 5-24.

Erikson, E. H. (1959). Identity and the life cycle. Selected papers.

Erikson, E. H. (1963). Childhood and society (Rev. ed.). New York: Norton.

Erikson, E. H. (1968). Psychoanalysis and Theories of Man.(Book Reviews: Identity: Youth and Crisis; Childhood and Society (1950)). Science, 161, 257-258.

Frederick, S. (2005). Cognitive reflection and decision making. Journal of Economic Perspectives, 19(4), $25-42$.

Freud, S. (1923). The libido theory. General Psychological Theory: Papers on Metapsychology, 180-184.

Gignac, G. E. (2014). Dynamic mutualism versus g factor theory: An empirical test. Intelligence, 42, 8997.

Gilligan, C. (1977). In a different voice: Women's conceptions of self and of morality. Harvard Educational Review, 47(4), 481-517.

Hackman, J. R., \& Oldham, G. R. (1975). Development of the job diagnostic survey. Journal of Applied Psychology, 60(2), 159.

Hage, J., \& Aiken, M. (1967). Relationship of centralization to other structural properties. Administrative Science Quarterly, 72-92.

Hage, J., \& Aiken, M. (1970). Social change in complex organizations (Vol. 41). Random House Trade.

Hauser, R. M. (1970). Context and consex: a cautionary tale. American Journal of Sociology, 75(4, Part 2), 645-664.

Heath, D. (1978). A model of becoming a liberally educated and mature student. Encouraging Development in College Students, 189-212.

Heath, D. H. (1968). Growing up in college. Jossey-Bass.

Hersey, P., \& Blanchard, K. H. (1969). Life cycle theory of leadership. Training \& Development Journal.

Hersey, P., \& Blanchard, K. H. (1977). Management of Organizational Behavior: utilizing human resources. New Jersey: Prentice Hall: Englewood Cliffs.

Hitt, M. A., Keats, B. W., \& DeMarie, S. M. (1998). Navigating in the new competitive landscape: Building strategic flexibility and competitive advantage in the 21st century. The Academy of Management Executive, 12(4), 22-42.

Hofmann, D. A., \& Gavin, M. B. (1998). Centering decisions in hierarchical linear models: Implications for research in organizations. Journal of Management, 24(5), 623-641. 
Hu, L. t., \& Bentler, P. M. (1999). Cutoff criteria for fit indexes in covariance structure analysis: Conventional criteria versus new alternatives. Structural Equation Modeling: A Multidisciplinary Journal, 6(1), 1-55.

Huber, G. P. (1991). Organizational learning: The contributing processes and the literatures. Organization Science, 2(1), 88-115.

Hunter, L., Beaumont, P., \& Lee, M. (2002). Knowledge management practice in Scottish law firms. Human Resource Management Journal, 12(2), 4-21.

Hyman, H. H., \& Wright, C. R. (1979). Education's lasting influence on values.

Jarvis, W. B. G., \& Petty, R. E. (1996). The need to evaluate. Journal of Personality Social Psychology, 70(1), 172.

Kaufman, P., \& Feldman, K. A. (2004). Forming identities in college: A sociological approach. Research in Higher Education, 45(5), 463-496.

Kelloway, E. K., \& Barling, J. (2000). Knowledge work as organizational behavior. International Journal of Management Reviews, 2(3), 287-304.

Kirton, M. J. (1981). A reanalysis of two scales of tolerance of ambiguity. Journal of Personality Assessment, 45(4), 407-414.

Knefelkamp, L., Widick, C., \& Parker, C. A. (1978). Editors' notes: Why bother with theory? New Directions for Student Services, 1978(4), vii-xvi.

Kohlberg, L. (1969). Stage and sequence: The cognitive-developmental approach to socialization. Rand McNally.

Kohlberg, L. (1972). A cognitive-developmental approach to moral education. Humanist, 32(6), 13.

Kohlberg, L. (1981). Essays on moral development: The philosophy of moral development (Vol. 1). San Francisco: Haper \& Row.

Kohlberg, L. (1984). Essays on moral development: Vol. 2. The psychology of moral development: Moral stages, their nature and validity. San Francisco: Harper \& Row.

Kohn, M. L. (1969). Class and Conformity (Homewood, IL. IL. IU., Dorsey.

Kruglanski, A. W. (1989). The psychology of being" right": The problem of accuracy in social perception and cognition. Psychological Bulletin, 106(3), 395.

Kruglanski, A. W. (1990). Lay epistemic theory in social-cognitive psychology. Psychological Inquiry, 1(3), 181-197.

Kruglanski, A. W., \& Freund, T. (1983). The freezing and unfreezing of lay-inferences: Effects on impressional primacy, ethnic stereotyping, and numerical anchoring. Journal of Experimental Social Psychology, 19(5), 448-468.

Kuhn, D., Black, J., Keselman, A., \& Kaplan, D. J. C. (2000). The development of cognitive skills to support inquiry learning. Cognition Instruction, 18(4), 495-523.

Lipsitz, L. (1965). Working-class authoritarianism: A re-evaluation. American Sociological Review, 30(1), 103-109.

Loevinger, J. (1976). Ego development: Conceptions and theories.

Machlup, F. (1962). The production and distribution of knowledge in the United States (Vol. 278). Princeton: university press.

Mandt, E. (1978). Managing the Knowledge Worker of the Future. Personnel Journal, 57(3), 138143,162 .

Marcia, J. E. (1964). Determination and consistant validity of ego identity status. The Ohio State University.

Marcia, J. E. (1966). Development and validation of ego-identity status. Journal of Personality and Social Psychology, 3(5), 551.

Maruta, R. (2012). Transforming knowledge workers into innovation workers to improve corporate productivity. Knowledge-Based Systems, 30, 35-47.

Mayer, R. (2002). Multimedia learning Psychology of learning and motivation (Vol. 41, pp. 85-139): Elsevier.

52 Journal of Organizational Psychology Vol. 19(5) 2019 
McCrae, R. R., \& Costa Jr, P. T. (1994). The stability of personality: Observations and evaluations. Current Directions in Psychological Science, 3(6), 173-175.

McKeough, A., \& Sanderson, A. (1996). Teaching storytelling: A microgenetic analysis of developing narrative competency. Journal of Narrative and Life History, 6(2), 157-192.

Meyer, J. P., \& Allen, N. J. (1984). Testing the "side-bet theory" of organizational commitment: Some methodological considerations. Journal of Applied Psychology, 69(3), 372.

Moore, L. M., \& Ovadia, S. (2006). Accounting for spatial variation in tolerance: The effects of education and religion. Social Forces, 84(4), 2205-2222.

Moorman, R. H., Niehoff, B. P., \& Organ, D. W. (1993). Treating employees fairly and organizational citizenship behavior: Sorting the effects of job satisfaction, organizational commitment, and procedural justice. Employee Responsibilities Rights Journal, 6(3), 209-225.

Morris, T., \& Empson, L. (1998). Organisation and expertise: An exploration of knowledge bases and the management of accounting and consulting firms. Accounting, Organizations and Society, 23(5), 609-624.

Myers, I. B. (1976). Introduction to type ${ }^{\circledR}$. CPP.

Myers, I. B., McCaulley, M. H., \& Most, R. (1985). Manual: A guide to the development and use of the Myers-Briggs Type Indicator (Vol. 1985). Consulting Psychologists Press Palo Alto, CA.

Nonaka, I., \& Takeuchi, H. (1995). The knowledge-creating company: How Japanese companies create the dynamics of innovation. Oxford university press.

Noyelle, T. (1990). Toward a new labor market segmentation. Skills, Wages and Productivity in the Service Sector, 212-224.

Nunnally, J. (1978). C.(1978). Psychometric theory, 2.

OECD. (2001). OECD Science, Technology and Industry Scoreboard 2001: Towards a Knowledge-based Economy: Organisation for Economic Co-operation and Development.

Parker, C., Widick, C., \& Knefelkamp, L. (1978). Editors' notes: Why bother with theory. Applying new developmental findings. New Directions for Student Services, 4.

Pascarella, E. T. (1985). College environmental influences on learning and cognitive development: A critical review and synthesis. Higher Education: Handbook of Theory and Research, 1(1), 1-61.

Pascarella, E. T., Edison, M., Nora, A., Hagedorn, L. S., \& Terenzini, P. T. (1996). Influences on students' openness to diversity and challenge in the first year of college. The Journal of Higher Education, 67(2), 174-195.

Pascarella, E. T., \& Terenzini, P. T. (1991). How college affects students (Vol. 1991). Jossey-Bass San Francisco.

Pascarella, E. T., \& Terenzini, P. T. (2005). How college affects students: A third decade of research (Vol. 2). San Francisco: Jossey-Bass.

Pennings, J. (1973). Measures of organizational structure: A methodological note. American Journal of Sociology, 79(3), 686-704.

Perkins, D. (1995). Outsmarting IQ: The emerging science of learnable intelligence. Simon and Schuster.

Perkins, D., Tishman, S., Ritchhart, R., Donis, K., \& Andrade, A. (2000). Intelligence in the wild: A dispositional view of intellectual traits. Educational Psychology Review, 12(3), 269-293.

Perkins, D. N., Jay, E., \& Tishman, S. (1993). Beyond abilities: A dispositional theory of thinking. Merrill-Palmer Quarterly, (1982-), 1-21.

Perry, W. G. (1970). Forms of intellectual and ethical development in the college years. New York: Holt, Rinehart and Winston. Inc. 連結.

Perry, W. G. (1981). Cognitive and ethical growth. (|).

Phye, G. (1997). Inductive reasoning and problem solving: The early grades. Handbook of Academic Learning Construction of Knowledge, 451-471.

Powell, W. W., \& Snellman, K. (2004). The knowledge economy. Annual Review of Sociology, 199-220.

Prusak, L. (2009). Knowledge in organisations. Routledge.

Quinn, R. W. (2005). Flow in knowledge work: High performance experience in the design of national security technology. Administrative Science Quarterly, 50(4), 610-641. 
Rattazzi, A. M. M., Bobbio, A., \& Canova, L. (2007). A short version of the Right-Wing Authoritarianism (RWA) Scale. Personality and Individual Differences, 43(5), 1223-1234.

Raudenbush, S. W., \& Bryk, A. S. (2002). Hierarchical linear models: Applications and data analysis methods (Vol. 1): Sage.

Reich, R. B. (1993). The work of nations : preparing ourselves for 21st century capitalism. New York Vintage Books,

Richter, L., \& Kruglanski, A. W. (1998). Seizing on the latest: Motivationally driven recency effects in impression formation. Journal of Experimental Social Psychology, 34(4), 313-329.

Ritchie, S. J., Bates, T. C., \& Deary, I. J. (2015). Is education associated with improvements in general cognitive ability, or in specific skills? Developmental Psychology, 51(5), 573.

Ritchie, S. J., \& Tucker-Drob, E. M. (2018). How much does education improve intelligence? A metaanalysis. Psychological Science, 29(8), 1358-1369.

Roberts, B. W., Walton, K. E., \& Viechtbauer, W. (2006). Patterns of mean-level change in personality traits across the life course: a meta-analysis of longitudinal studies. Psychological Bulletin, $132(1), 1$.

Robertson, M., \& Swan, J. (2003). 'Control-What Control?'Culture and Ambiguity Within a Knowledge Intensive Firm*. Journal of Management Studies, 40(4), 831-858.

Rodgers, R. F. (1989). Student development. Student Services. A Handbook for the Profession, 117-164.

Rodgers, R. F. (1990). Recent theories and research underlying student development. College Student Development: Theory and Practice for the ACPA Media Publication, 49, 27-79.

Sapir, E. (1934). The Emergence of the Concept of Personality in a Study of Cultures. The Journal of Social Psychology, 5(3), 408-415.

Schaubroeck, J., Ganster, D. C., \& Jones, J. R. (1998). Organization and occupation influences in the attraction-selection-attrition process. Journal of Applied Psychology, 83(6), 869.

Schneider, B. (1987). The people make the place. Personnel Psychology, 40(3), 437-453.

Schommer, M. (1990). Effects of beliefs about the nature of knowledge on comprehension. Journal of Educational Psychology, 82(3), 498.

Shuell, T. J. (1990). Phases of meaningful learning. Review of Educational Research, 60(4), 531-547.

Spearman, C. (1904). "General Intelligence," objectively determined and measured. The American Journal of Psychology, 15(2), 201-292.

Stanback, T. M. (1979). Understanding the service economy: Employment, productivity, location. Baltimore: Johns Hopkins University Press.

Stouffer, S. A. (1963). Methods of research used by American social scientists. The Behavioral Sciences Today, 72.

Strange, C. C. (2003). Dynamics of campus environments. Student Services: A Handbook for the Profession, 4, 297-316.

Strenze, T. (2007). Intelligence and socioeconomic success: A meta-analytic review of longitudinal research. Intelligence, 35(5), 401-426.

Swart, J., \& Kinnie, N. (2003). Sharing knowledge in knowledge-intensive firms. Human Resource Management Journal, 13(2), 60-75.

Tatzel, M. (1980). Tolerance for ambiguity in adult college students. Psychological Reports, 47(2), 377378.

Tinto, V. (1975). Dropout from higher education: A theoretical synthesis of recent research. Review of Educational Research, 45(1), 89-125.

Tinto, V. (1987). Leaving college: Rethinking the causes and cures of student attrition. ERIC.

Troldahl, V. C., \& Powell, F. A. (1965). A short-form dogmatism scale for use in field studies. Social Forces, 44(2), 211-214.

Tucker-Drob, E. M. (2009). Differentiation of cognitive abilities across the life span. Developmental Psychology, 45(4), 1097.

Vogt, W. P. (1997). Tolerance \& education: Learning to live with diversity and difference. Sage Publications, Inc.

54 Journal of Organizational Psychology Vol. 19(5) 2019 
Von Nordenflycht, A. (2010). What is a professional service firm? Toward a theory and taxonomy of knowledge-intensive firms. Academy of Management Review, 35(1), 155-174.

Webster, D. M., \& Kruglanski, A. W. (1994). Individual differences in need for cognitive closure. Journal of Personality Social Psychology, 67(6), 1049.

Weil, F. D. (1985). The variable effects of education on liberal attitudes: A comparative-historical analysis of anti-Semitism using public opinion survey data. American Sociological Review, 458474.

Weissenstein, A., Ligges, S., Brouwer, B., Marschall, B., \& Friederichs, H. (2014). Measuring the ambiguity tolerance of medical students: a cross-sectional study from the first to sixth academic years. BMC Family Practice, 15(1), 6.

Wikström, S., \& Norman, R. (1994). Knowledge and value: A new perspective on transformation corporative. Routledge.

Williams, J. A. (1966). Regional differences in authoritarianism. Social Forces, 273-277.

Williams J. A. Jr,, Nunn, C. Z., \& Peter, L. S. (1976). Origins of tolerance: Findings from a replication of Stouffer's Communism, conformity, and civil liberties. Social Forces, 55(2), 394-408.

Xie, C., Bagozzi, R. P., \& Grønhaug, K. (2015). The role of moral emotions and individual differences in consumer responses to corporate green and non-green actions. Journal of the Academy of Marketing Science, 43(3), 333-356.

Zakrisson, I. (2005). Construction of a short version of the Right-Wing Authoritarianism (RWA) scale. Personality Individual Differences, 39(5), 863-872. 